\title{
The “Devil's Door" in Wroxhall Abbey Church
}

\section{Charlotte S. Burne}

To cite this article: Charlotte S. Burne (1908) The "Devil's Door" in Wroxhall Abbey Church, Folklore, 19:4, 458-459, DOI: 10.1080/0015587X.1908.9719847

To link to this article: http://dx.doi.org/10.1080/0015587X.1908.9719847

$$
\text { 曲 Published online: } 14 \text { Feb } 2012 .
$$

Submit your article to this journal

Џll Article views: 1

Q View related articles $\longleftarrow$ 
mourns with tears and lamentations of wind. But after, when the former and latter rains have passed, and Yum R'baiza, "the Days of Grass," have come! Then are the winds soft, and the trees and fields are green and pink and white, and everywhere is laid a thick carpet of flowers. And the scents ! The air is laden with them. Knowest thou why is all this? It is because in the days of "Yum R'baiza" are lit the censers of "Jinnat" paradise, and what we notice are the faint breathings thereof. What must it be like there, then? There, where the souls of the blessed disport themselves?

\section{The "Devil's Door" in Wroxhall Abbey Church.}

(Plate XII.)

Wroxhall, according to Dugdale, was originally an outlying hamlet in the parish of Honily or Honeley, Warwickshire, where, in the time of Stephen, Hugh de Hatton of Hatton, a neighbouring parish, founded a house of Benedictine nuns, dedicating the church to St. Leonard, the woodland saint of Limoges, patron of prisoners. A legend, recorded in the fifteenth century in the Chartulary of the convent, told that Hugh de Hatton, having been taken captive in the Crusades, prayed to St. Leonard, and was then miraculously transported back to Warwickshire, where his wife failed to recognise him till he produced the half of the ring he had broken with her ere his departure, when the two halves were found to fit and were miraculously welded together. The Priory, erected on the spot on his estates in the forest of Arden where the meeting took place, was Hugh's thank-offering for his deliverance, and he endowed it with the Church of Hatton and with all his lands in the parish of Honily. A century later, Honily itself was granted by Simon de Montfort to the Austin Canons of Kenilworth, and Wroxhall in course of time became a separate parish. The living is still a donative, in the gift of the proprietor of the estate. The lay owners after the Dissolution 


\section{PLATE XII.}

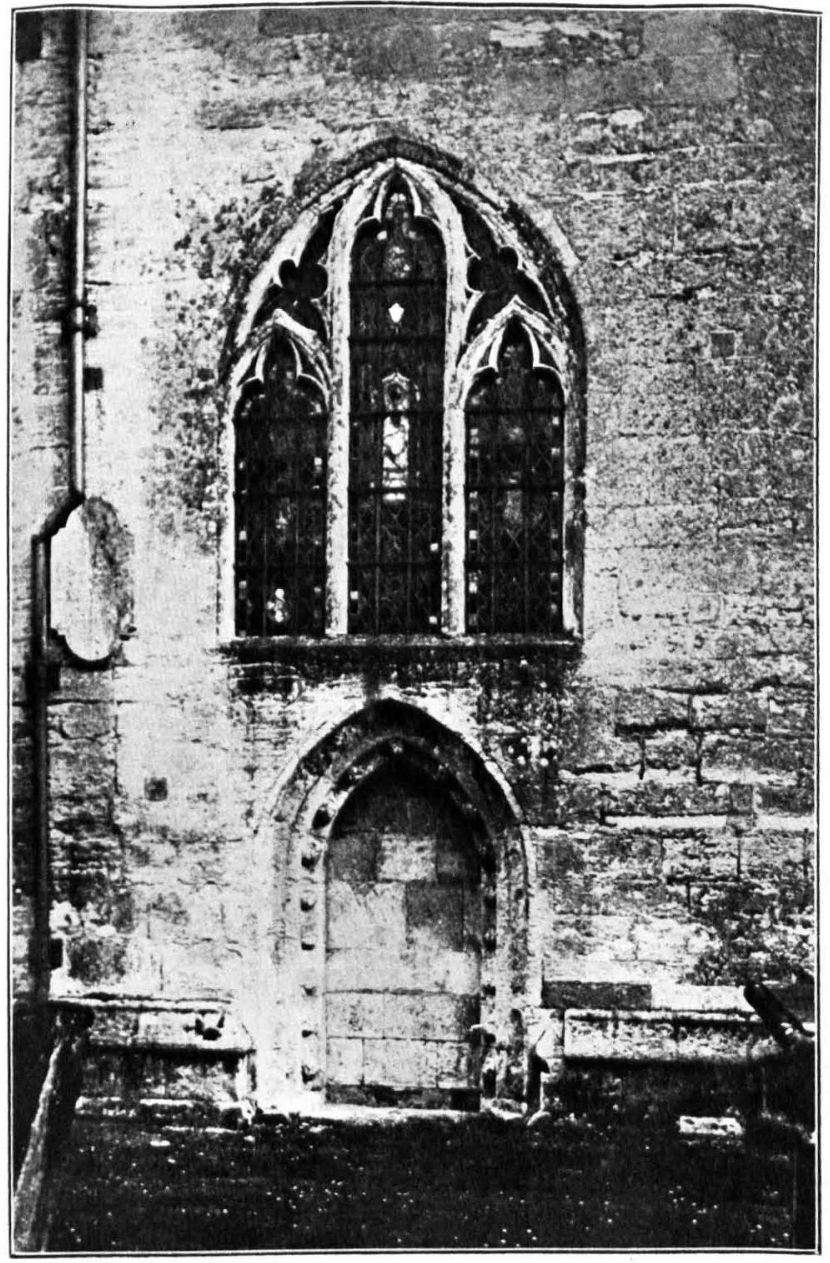

Leonardson \& Co.

The Devil's Door, Wroxhall Abbey. 


\section{Collectanea.}

built a mansion on the site of the domestic buildings, but the Priory Church (now commonly called the Abbey), which occupied the north side of the quadrangle, remained and still remains the parish church of the little hamlet. On its northern or outward side are five large windows, the middle one of which is shorter than the others to allow of a door underneath (Plate XII.). This door has long been walled up and no trace of it is visible outside, but tradition (as preserved in the Wren family, the owners from I713 to I86r), called it the "Devil's Door" and declared that it was 6pened only at Baptisms and Exorcisms, to allow of the exit of the Devil who might otherwise meet and enter into some one coming in by the usual entrance nearer the north-west angle of the building.

Mr. H. W. Poole (Barnet) informs me through Mr. Milne that the custom of leaving open the north door of the church at a Baptism-or at any rate the idea that it ought to be so left open-for the use of the Devil, is constant in Gloucestershire. And Brand has many notes of the custom of reserving the north side of the churchyard for the burial of unbaptized persons and suicides (Ellis's Brand, ii. 292).

Charlotte S. Burne.

\section{The Legend of Savaddan Lake.}

Nor far from the foot of the Black Mountains of Brecon, in a low lovely fertile valley, under the shadow of Mount Troedd, lies Savaddan Lake (the Llangorse Lake of our maps). The following tradition is told regarding it:

Many years ago, when all the surrounding country was under Prince Tewdryg, the bed of the lake was occupied by Savaddan, a town identified with the Roman Loventium. It was, at the time of our story, ruled by a maiden, the beautiful and highspirited Gwenonwy, who was under Tewdryg's suzerainty. From far and wide came suitors for her hand and throne, but none found such favour as the noble Gruffydd, youngest son of a 